УДК 005.95/.96:338.47

DOI: $10.25140 / 2411-5215-2020-4(24)-34-42$

Олена Парубеиь, Ірина Кичко

\title{
НАПРЯМИ ВИКОРИСТАННЯ ТЕХНОЛОГІЙ НR-МЕНЕДЖМЕНТУ У ТРАНСПОРТНОМУ СЕКТОРІ УКРАЇНИ
}

\section{Елена Парубеи, Ирина Кичко \\ НАПРАВЛЕНИЯ ИСПОЛЬЗОВАНИЯ ТЕХНОЛОГИЙ НR-МЕНЕДЖМЕНТА В ТРАНСПОРТНОМ СЕКТОРЕ УКРАИНЫ}

\author{
Olena Parubets, Iryna Kychko \\ WAYS OF USING HR-MANAGEMENT TECHNOLOGIES \\ IN THE TRANSPORT SECTOR OF UKRAINE
}

У статті здійснено аналіз темпів зміни кількості суб'єктів господарювання окремих видів транспорту та чисельності зайнятих на них працівників. Виявлено сучасні проблеми в управлінні персоналом у розрізі окремих видів транспорту Украӥни. Для усунення наявних проблем запропоновано доповнювати традииійні методи набору персоналу сучасними, а саме хедхантингом, рекрутингом, скринінгом, а у випадку звільнення робітників технологією аутплейсмент. Обтрунтовано дочільність використання технологій HR-менеджменту для удосконалення управління персоналом підприємств різних видів транспорту з метою їх швидкого адаптування до нових викликів, пов'язаних зі зміною зовнішнього і внутрішнього середовиша.

Ключові слова: інновачії; технології HR-менеджменту; управління персоналом; хедхантинг; рекрутинг; скринінг; аутплейсмент; транспортна система Украӥни.

Табл.: 2. Бібл.: 18.

В статье осуществлен анализ темпов изменения количества субъектов хозяйствования в разрезе отдельных видов транспорта и численности занятых на них работников. Выявлены современные проблемы в управлении персоналом в разрезе отдельных видов транспорта Украины. Для устранения существующих проблем предложено дополнять традииионные методы набора персонала современныли, а именно хедхантингом, рекрутингом, скринингом, а в случае увольнения рабочих технологией аутплейсмент. Обоснована иелесообразность использования технологий HR-менеджмента для совершенствования управления персоналом предприятий различных видов транспорта с иелью их быстрой адаптации к новым вызовам, связанным с изменением внешней и внутренней среды.

Ключевые слова: инновации; технологии HR-менеджмента; управления персоналом; хедхантинг; рекрутинг, скрининг; аутплейсмент; транспортная система Украины.

Табл.: 2. Библ.: 18

The article analyzes the rate of change in the number of business entities in terms of certain types of transport and the number of employees engaged in this sector. It has been revealed current problems in personnel management in the context of certain types of transport of Ukraine. To eliminate the existing problems, it has been proposed to supplement the traditional methods of recruitment with modern ones, namely headhunting, recruitment, screening, as well as with the technology of outplacement in case of dismissal of workers. It has been substantiated the expediency of using HR-management technologies in order to improve personnel management of enterprises of different types of transport for their quick adaptation to new challenges associated with changing external and internal environment.

Keywords: innovations; HR-management technologies; personnel management; headhunting; recruiting; screening; outplacement; transport system of Ukraine.

Table: 2. References: 18 .

JEL Classification: J24; J28; J48; J88; L91; M51

Постановка проблеми. Розвиток конкурентоспроможного, ефективно функціонуючого транспортного сектору є одним зі стратегічних орієнтирів національної економіки. На фоні існування низки системних проблем у функціонуванні транспортного сектору в умовах пандемії добавилися ще і проблеми, пов'язані зі збереженням контингенту персоналу під впливом трансформації ринку праці. Призупинення діяльності транспорту в умовах карантинних обмежень призвело до скорочення чисельності працюючих, переходу кваліфікованих спеціалістів в інші компанії, зокрема зарубіжні, або зовсім до зміни професії. Загальновідомим $\epsilon$ той факт, що головним ресурсом будь-якого підприємства $\epsilon$ трудові ресурси. Не винятком $є$ і підприємства транспорту, які в умовах значного скорочення обсягу перевезень, особливо пасажирських, повинні розробляти стратегії виходу 3 коронакризи й обгрунтовувати напрями поступового відновлення докризових показників діяльності. 
ГАЛУЗЕВИЙ АСПЕКТ РОЗВИТКУ НАЦІОНАЛЬНОГО ГОСПОДАРСТВА

Суттєво покращити відбір та забезпечити збереження висококваліфікованого персоналу, впровадити нові підходи до стимулювання і розвитку навичок працівників, що відповідають рівню інформатизації процесу перевезень, підприємства транспорту можуть завдяки розширенню сфери застосування технологій HR-менеджменту. Дослідження необхідності вдосконалення управління персоналом, задіяним на різних видах транспорту на основі розвитку технологій HR-менеджменту та обгрунтування напрямів їх практичного застосування зумовили актуальність обраної теми дослідження.

Аналіз останніх досліджень та публікацій. Інноваційні методи управління персоналом підприємств різних видів транспорту України стали предметом дослідження багатьох вітчизняних учених.

Н. Чернова, Д. Сурмило акцентують увагу на стратегічному плануванні кадрового потенціалу транспортної галузі, зазначаючи, що в умовах кризи одним із пріоритетних заходів $\epsilon$ ефективне корпоративне управління, в основі якого, на нашу думку, повинно бути вимірювання продуктивності праці з урахуванням специфічних особливостей різних видів транспорту з використанням комплексного методу вирівнювання такого показника [14].

В. Смачило [12], досліджуючи архітектоніку трансформацій кадрового потенціалу підприємств транспорту, вважає, що відсутність статистичних даних стосовно аналізу працюючих на транспорті за окремими віковими групами призводить до нераціональної системи управління персоналом. У такій системі не враховується різниця цінностей поколінь, що, на думку авторки, потребує застосування такого критерію класифікації методів управління кадровим потенціалом, який би врахував специфіку поколінь X, Y, Z.

Досліджуючи проблеми кадрового потенціалу Укрзалізниці, I. Назаренко наголошує на необхідності розроблення організаційно-економічного механізму управління кадровим потенціалом, називаючи однією з причин незадовільного стану Укрзалізниці саме низький рівень управління людськими ресурсами. Авторкою серед основних проблем управління персоналом галузі виділені низька заробітна плата, що спричиняє відтік кваліфікованих працівників, та необхідність приведення кількості працівників до середньоєвропейських показників шляхом скорочення [8].

Автори роботи [6] зазначають, що для залізничного транспорту, враховуючи його специфічні галузеві особливості діяльності, більш доцільним у процесі оцінювання і підготовки персоналу є застосування компетентнісного підходу. Зазначений підхід інтегрує два поняття «компетенція» - навички, знання, інтелектуальна складова та «компетентність» як готовність і здатність виконувати різноманітні завдання. Також В. Компанієць, В. Польова вказують на те, що на підприємствах залізничного транспорту компетентнісної оцінки персоналу немає. При цьому широко використовується метод масового усереднення замість більш передового методу, а саме управління персоналом з урахуванням особистості працівника.

Досліджуючи організаційно-економічні аспекти підготовки моряків Г. Коба та T. Шелест зазначають, що така система підготовки і дипломування моряків $є$ однією 3 найважливіших складових забезпечення безпеки судноплавства. Остання повинна оцінюватися на основі кількості задокументованих випадків некомпетентності або неправильних дій членів екіпажу судна. Якісна підготовка моряків потребує оновлення матеріально-технічної бази навчальних закладів, судноплавних компаній, тісної взаємодії стейкхолдерів та збільшення фінансування за рахунок розвитку державно-приватного партнерства [5].

О. Криворучко, Т. Водолажська пропонують використовувати загальну й інструментальну стратегії управління персоналом автотранспортних підприємств. При їх розробці необхідно побудувати морфологічну матрицю і провести комбінування стратегій за видами бізнес-стратегій, кадрової політики та персоналу автотранспортних підприємств [7]. 
Виділення недосліджених частин загальної проблеми. Незважаючи на велику кількість наукових праць, присвячених удосконаленню системи управління персоналом підприємств транспорту, питання стосовно впровадження і розвитку інноваційних технологій HR-менеджменту потребують проведення подальших досліджень сфери їх застосування та обгрунтування економічної доцільності використання.

Мета статті полягає в дослідженні напрямів використання сучасних технологій HRменеджменту в діяльності суб'єктів господарювання транспортного сектору України для удосконалення системи управління персоналом та зменшення впливу людського фактору на стан безпеки вантажних і пасажирських перевезень.

Виклад основного матеріалу. Перш ніж зупинитися на дослідженні проблем і перспектив розвитку системи управління персоналом підприємств транспорту, проведемо аналіз кількісного складу суб'єктів господарювання на транспорті та чисельності працюючих на них робітників. Статистичні дані кількості підприємств транспорту за 20172019 рр. зведемо в табл. 1.

Таблиця 1

Кількість суб'єктів господарювання за видами транспорту

\begin{tabular}{|c|c|c|c|}
\hline Рік & $\begin{array}{c}\text { Кількість суб'єктів } \\
\text { господарювання, } \\
\text { одиниць }\end{array}$ & $\begin{array}{c}\text { 3 них фізичні } \\
\text { особи-підприсмці, осіб }\end{array}$ & $\begin{array}{c}\text { У відсотках до загального } \\
\text { показника суб'сктів } \\
\text { господарювання на транспорті, \% }\end{array}$ \\
\hline \multicolumn{4}{|c|}{ Наземний і трубопровідний транспорт } \\
\hline 2017 & 75732 & 68209 & 90,1 \\
\hline 2018 & 70313 & 62288 & 88,6 \\
\hline 2019 & 74647 & 65773 & 58,1 \\
\hline \multicolumn{4}{|c|}{ Водний транспорт } \\
\hline 2017 & 248 & 128 & 49,6 \\
\hline 2018 & 235 & 116 & 49,4 \\
\hline 2019 & 255 & 126 & 14,9 \\
\hline \multicolumn{5}{|c|}{ Авіаційний транспорт } \\
\hline 2017 & 121 & 18 & 13,0 \\
\hline 2018 & 115 & 19 & 15,6 \\
\hline 2019 & 122 &
\end{tabular}

Джерело: складено авторами на основі [1].

Як видно з даних, наведених у табл. 1, до пандемії, тобто у 2019 р., кількість підприємств транспорту за всіма його видам мала тенденцію до зростання в порівнянні 3 попередніми роками періоду, що аналізується.

Кількісний склад працівників транспортної галузі за останні три роки наведено в табл. 2.

Таблиця 2

Кількість зайнятих працівників у транспортному секторі Украӥни

\begin{tabular}{|c|c|c|c|}
\hline Рік & $\begin{array}{l}\text { Кількість зайнятих } \\
\text { працівників, осіб }\end{array}$ & $\begin{array}{c}3 \text { них у фізичних } \\
\text { осіб-підприсмців, осіб }\end{array}$ & $\begin{array}{c}\text { У відсотках до загального } \\
\text { показника суб'сктів } \\
\text { господарювання на транспорті, \% }\end{array}$ \\
\hline \multicolumn{4}{|c|}{ Наземний і трубопровідний транспорт } \\
\hline 2017 & 518123 & 49099 & 9,5 \\
\hline 2018 & 514633 & 58969 & 11,5 \\
\hline 2019 & 517695 & 61152 & 11,8 \\
\hline \multicolumn{4}{|c|}{ Водний транспорт } \\
\hline 2017 & 3921 & 19 & 0,5 \\
\hline 2018 & 3813 & 28 & 0,7 \\
\hline 2019 & 4078 & 27 & 0,7 \\
\hline \multicolumn{4}{|c|}{ Авіаційний транспорт } \\
\hline 2017 & 18490 & - & - \\
\hline 2018 & 18032 & - & - \\
\hline 2019 & - & - & - \\
\hline
\end{tabular}

Джерело: складено авторами на основі [1]. 
ГАЛУЗЕВИЙ АСПЕКТ РОЗВИТКУ НАЦІОНАЛЬНОГО ГОСПОДАРСТВА

У 2019 р., як видно з даних табл. 2, спостерігалося збільшення чисельності працівників у порівнянні з 2018 р. майже на всіх видах транспорту, крім авіаційного, статистичні дані по якому за останній звітний рік відсутні. Суттєвий вплив на показники діяльності транспорту здійснила пандемія спричинена COVID-2019. Враховуючи зазначене в розрізі окремих видів транспорту можна виділити такі проблеми в управлінні персоналом:

- автомобільний транспорт - наявність нелегальних приватних перевізників, неофіційне працевлаштування водіїв, особливо на вантажному транспорті;

- залізничний транспорт - неналежні умови праці, низький рівень заробітної плати залізничників, виконання поряд із посадовими обов'язками низки неформальних обов'язків і доручень ;

- водний транспорт - сезонний характер роботи працівників; ненадійна система захисту прав моряків при роботі на суднах під іноземними прапорами, робота без укладеного трудового контракту, порушення роботодавцями умов трудових контрактів моряків;

- авіаційний транспорт - суттєве скорочення персоналу, зокрема, , бортпровідників та обслуговуючого персоналу аеропортів, працевлаштування висококваліфікованих працівників на суміжних підприємствах, які співпрацюють з аеропортами тощо [9].

Вирішення вищезазначених проблем в умовах невизначеності й ризику потребує розвитку на транспорті сучасної та ефективної системи управління персоналом, що базується на використанні технологій HR-менеджменту. Такі технології є найбільш орієнтованими на сучасні потреби персоналу підприємств транспорту.

В умовах пандемії відбулося переосмислення методів організації і управління персоналом підприємств транспорту. Розвиток інформаційних і цифрових технологій, запровадження штучного інтелекту в діяльність транспортного сектору спричиняє впровадження цифрових платформ та різноманітних новітніх інформаційних технологій на транспорті. 3 одного боку, це має безперечні переваги, пов'язані з цифровізацією транспортної галузі (мобільні додатки, електронний квиток тощо), а з іншого - призведе до зростання безробіття серед персоналу транспортних підприємств через причину максимальної автоматизації та комп'ютеризації робочих місць. Уже існують прогнози різних експертів щодо того, що впродовж найближчих десяти років може зникнути, наприклад, професія водія у зв'язку з появою безпілотних автомобілів, тракторів та іншої транспортної техніки, яка може управлятися дистанційно. Зростання меж використання відповідного програмного забезпечення, яке дозволяє розробляти більш раціональні маршрути пересування транспортних засобів, відстежувати переміщення пасажирів і вантажу в дорозі, ефективно планувати логістичні операції, здійснювати бухгалтерські операції тощо призведе до ще більшого скорочення персоналу транспортних підприємств у майбутньому. У такій ситуації необхідно змінювати наявні підходи до управління персоналом, доповнювати традиційні методи набору персоналу сучасними, а саме хедхантингом, рекрутингом, скринінгом, а у випадку звільнення робітників технологією аутплейсмент. Робітники, зайняті в транспортному секторі, повинні швидко адаптуватися до нових вимог, постійно підвищувати рівень своєї кваліфікації, вирішувати нестандартні завдання та протистояти викликам зовнішнього і внутрішнього середовища.

Початковим етапом системи управління персоналом $є$ професійний набір кадрів, який включає в себе методи, що використовуються для забезпечення найкращого складу потенційної кваліфікованої робочої сили, кандидатів з якої вони зможуть за необхідності найняти. Від ефективності методу професійного набору персоналу залежить ефективність діяльності та конкурентоспроможність суб'єктів господарювання на транспорті [4].

Набір персоналу поділяється на дві складові, які мають свої недоліки і переваги: 
- внутрішній набір - серед його переваг основними є можливість просування по кар'єрних сходах, порівняно низькі витрати на заповнення вакансій та швидке їх внутрішне заміщення, підвищення кваліфікації працівників, покращення соціальнопсихологічного клімату, запобігання плинності кадрів, зростання продуктивності праці, до недоліків можна віднести обмежені можливості вибору кадрів, виникнення суперництва між претендентами на посаду, можливість конфлікту інтересів тощо;

- зовнішній набір - як перевага, має широкі можливості вибору кандидатів; нові вектори розвитку транспортної діяльності; як недолік, більші витрати часу на залучення працівників; високий ступінь ризиків через незнання людини; тривалий період адаптації працівника у сталому колективі; блокування можливостей просування по службі; зростання плинності кадрів; збільшення ймовірності конфліктів.

В умовах пандемії перспективними інноваційними формами зайнятості стають комунікаційні онлайн-технології, які дають можливість розвитку інформаційнокомунікаційних технологій у режимі поточного часу. У свою чергу, фахівцям з HR менеджменту доводиться знаходити форми та методи управління персоналом поза межами робочого місця, вирішуючи проблему управління віддаленою робочою силою [2].

Це потребує формування у транспортному секторі єдиного інформаційнокомунікаційного поля для просторово-часового узгодження взаємодії персоналу різних видів транспорту в транспортному процесі [10].

Дедалі активніше для підвищення рівня продуктивності та креативності праці використовуються інженерні, інформаційні, комунікаційні та інші об'єкти інфраструктури (коворкінг загального офісного простору (co-working), створення на базі вебтехнологій інноваційних майданчиків для сформування інтерактивного комунікаційного середовища між співробітниками компанії для аналізу, реалізації інноваційних ідей) [3].

В умовах цифрової трансформації економіки в практиці HR-менеджменту особливе місце посідає використання перспективних інноваційних технологій інформаційнокомунікаційного спрямування, зокрема:

- аутсорсинг, тобто використання послуг HR-агентств, call-центрів, компаній (бухгалтерських, юридичних) замість найму персоналу на постійній основі;

- аутстафінг, за якого працівники працевлаштовуються в організації-провайдери;

- хедхантинг пошук, залучення і найм цінних, креативних працівників із високим потенціалом (які здебільшого не мають наміру міняти місце роботи), здатних вивести підприємства транспорту на новий рівень їхнього розвитку. У реаліях України хедхантинг часто трансформується з пошуку відомих професіоналів до підбору співробітників серед найкращих студентів;

- рекрутинг, який проводиться безпосередньо підприємством або рекрутинговим агентством, який дає можливість у разі потреби підібрати висококваліфікованих працівників. Значна частина операцій рекрутингу здійснюється за допомогою наявної автоматизованої бази кандидатів на посаду, а також із відгуків на оголошення, що були розміщені в засобах масової інформації [18]. Рекрутингові компанії сприяють пошуку кандидатів, підбору потенційних претендентів, відбору кандидатів, адаптації нових співробітників тощо [11].

Інноваційними, перспективними технологіями, що доцільно використовувати в управлінні персоналом підприємств транспорту є:

- скринінг, який здійснюється підприємством шляхом надсилання запитів до служб зайнятості, розміщення оголошень у мережі Інтернет та в засобах масової інформації і дає можливість проводити відбір персоналу за певними формальними ознаками: вік, стать, рівень освіти, наявність досвіду роботи; 
ГАЛУЗЕВИЙ АСПЕКТ РОЗВИТКУ НАЦІОНАЛЬНОГО ГОСПОДАРСТВА

- прескрептивна HR-аналітика, у межах якої здійснюється збір, обробка даних та оцінювання претендентів на вакантні посади, формування рейтингів працівників, прогноз плинності, формування кар'єрограм тощо.

Трансформація професійних вимог та структури компетенцій змінює і систему освіти, стимулює навчання протягом усього життя. Поряд зі звичними формами навчання (інструктаж, онлайн-курси, тренінги, наставництво, тематичні семінари) впроваджуються такі прогресивні методи розвитку й підготовки персоналу, як коучинг, бенчмаркинг, тимбілдинг, E-learning, геймифікація та ситуаційний аналіз. Ці технології об'єднують роботу, навчання, кар'єру та формування кадрового резерву.

Навчання персоналу можна втілювати за допомогою віртуальної реальності, адже використання комунікаційно-інформаційних технологій сприятиме створенню віртуального освітнього середовища, у якому можна використовувати сукупність різних засобів, методів, віртуальних образів із метою взаємодії з ними. Сам процес навчання нині в контексті здобуття знань, навичок, вмінь має бути безперервним та довічним, оскільки сьогодні освіта означає не лише знання, які були отримані у навчальному закладі, а також здатність знаходити шляхи вирішення непередбачуваних проблем, вміння діяти в реальних ситуаціях, ефективно використовувати свій потенціал. Перспективним на транспорті є більш інтенсивне використання таких методів навчання, як «case study» або ж кейс-метод (метод аналізу ситуацій), «Action Learning» навчання дією, «storytelling» (розповідь історій).

Метод «case study» або кейс-метод передбачає використання конкретних випадків, які можна назвати кейсами для групового аналізу, обговорення та створення рішень, являють собою суть даного методу. Кейс-метод не тільки відображає практичну проблему, а й одночасно робить актуальною ту сукупність знань, яку треба засвоїти при вирішенні саме цієї конкретної проблеми. За допомогою методу можна комплексно застосувати навчальну, аналітичну та практичну діяльність. Цілі методу безпосередньо залежать від конкретної ситуації. Кейс-метод спрямований на використання теоретичного матеріалу для аналізу конкретної проблеми, формування навичок, необхідних для оцінки ситуації, організації вмінь створення запитів та запитань, розробки запасного плану, формування навичок для конструктивної критики. Застосування методу «саse study» передбачає: poзбір ситуації за певним сценарієм дій, який обов'язково має включати самостійну роботу; використання методу мозкового штурму всіма членами команди, яка застосовує метод; запропоноване рішення має представлятися у формі публічного виступу, 3 можливістю внесення правок. Застосування кейс-методу стимулює індивідуальну активність працівників, формує позитивну мотивацію, змушуючи персонал працювати на результат, зменшує кількість пасивних працівників, формує певні особистісні якості, дає можливість самовдосконалюватись, по-іншому мислити та діяти [13].

«Action Learning» - навчання дією, для застосування якого необхідні люди - лідери, які захищають і просувають свій проєкт. Виникає робоча група, яка працює над окремими задачами, тим самим доводить проєкт до його логічного завершення - впровадження.

Навчання дією сприяє: реальному розвитку лідерського потенціалу учасника (кожен має просувати свій проєкт, починати взаємодію з іншими підрозділами, керівниками, спеціалістами), він поступово нарощує свій вплив і дійсно формує із себе сучасного лідера; реалізованому проєкту - якщо при використанні інших методів $є$ ймовірність нереалізації, то «асtion learning» гарантує результат; створення певної культури організації, працівники якої займаються самоосвітою. У процесі використання методології організація змінюється, тим самим створюючи культуру, у якій працівники можуть підтримувати один одного, навчати і тим самим просувати організацію вперед. 
Метод навчання дією найбільш ефективно буде працювати на транспортних підприємствах, у яких багато різноманітних функцій, наприклад виробничі підприємства (мають власне виробництво, логістику, продаж, маркетинг), для них цінність методу полягає саме у тому, що виникає обмін та перехрещення між функціональними підрозділами, адже будь-який проєкт пронизує організацію і дає змогу долучати різних працівників. Абсолютно виправданою буде користь методу для жорстко структурованих організацій: банків, страхових компаній, тобто ієрархічних фірм, яким важко побороти внутрішні обмеження відділів чи функцій [15].

Одним з інноваційних методів управління персоналом також $є$ «storytelling» - розповідь історій. Саме історія слугує носієм та розповсюджувачем корпоративних знань. Це ефективний метод донесення інформації до аудиторії шляхом розповіді історій про реальний досвід вітчизняних і зарубіжних підприємств транспорту виходу із кризових ситуацій. Даний метод поєднує в собі психологічні та управлінські аспекти і дозволяє не лише донести інформацію до аудиторії ефективно, а й змотивувати ії на певні дії й отримання максимально можливих результатів [17]. Сьогодні сторітелінг використовують не тільки в транспортному бізнесі, а й в інших сферах діяльності: маркетингу, коучингу, освіті.

Найдієвішим інноваційним методом управління персоналом, який має прийти на заміну звичайним тренінгам і використовуватися масово на підприємствах транспорту може стати коучинг. Коучинг це - своєрідний інструмент підвищення особистісної ефективності персоналу та його професійного розвитку. Зазначений метод має два напрями, які схожі між собою, але в той самий час $є$ відмінними один від одного. Перший напрям це взаємодія між керівниками та підлеглими, а другий - самостійна робота з менеджерами вищої ланки. Використання цього методу в управлінні персоналом підприємств транспорту підвищує продуктивність праці робітників на основі розвитку їхніх найкращих якостей і здібностей, розкриваючи внутрішній потенціал працюючих [16].

Висновки та пропозиції. До складу транспортного сектору входять рівноправні, юридично та економічно автономні суб'єкти транспортної діяльності як роботодавці, так і їх працівники, які в теперішніх складних умовах повинні будувати свої відносини на принципах партнерства, взаємної поваги, співробітництва і спрямованості на кінцевий результат. Трансформаційні зміни існуючої моделі ведення господарської діяльності на транспорті та ринку транспортних послуг, висувають нові вимоги до управління персоналом на основі розвитку технологій HR-менеджменту. Застосування останніх дасть змогу в умовах розвитку електронних транспортних послуг та послуг електронної логістики розвинути у працівників підприємств транспорту, необхідні для отримання в сучасних умовах конкурентних переваг на ринку праці надпрофесійних навичок soft skills та спеціальних вузькопрофесійних навичок hard skills.

\section{Список використаних джерел}

1. Державна служба статистики України. URL: http://www.ukrstat.gov.ua.

2. Іляш О. І., Блохін П. В. Майбутнє HR менеджменту: тенденції, ризики, мотивація. Ефективна економіка. 2018. № 10. URL: http://ojs.dsau.dp.ua/index.php/efektyvna-ekonomika/article/view/1484.

3. Інноваційна Україна 2020 : національна доповідь / за заг. ред. В. М. Гейця та ін. ; НАН України. Київ, 2015. 336 с.

4. Кичко І. І., Горбачова О. Ю. Інноваційні методи підбору та оцінки персоналу. Проблеми $i$ перспективи економіки та управління. 2017. № 2. С. 7-14.

5. Коба В. Г., Шелест Т. М. Економічні аспекти підготовки моряків в Україні. Водний транспорт. 2018. Вип. 1. С. 74-78.

6. Компанієць В. В., Польова В. В. Управління трудовою поведінкою працівників підприємства залізничного транспорту (соціокультурні домінанти) : монографія. Харків : Лідер, 2016. $298 \mathrm{c}$. 
ГАЛУЗЕВИЙ АСПЕКТ РОЗВИТКУ НАЦІОНАЛЬНОГО ГОСПОДАРСТВА

7. Криворучко О. М., Водолажська Т. О. Підхід до формування стратегій управління персоналом АТП. Економіка транспортного комплексу. 2013. Вип. 22. С. 97-107.

8. Назаренко І. Л., Труш І. М. Організаційно-економічний механізм управління кадровим потенціалом структурного підрозділу залізничного транспорту. Вісник економіки транспорту $i$ промисловості. 2019. № 66. С. 94-102.

9. Парубець О. М. Дослідження впливу коронакризи на стан транспортного сектору України. Проблеми і перспективи економіки та управління. Національний університет «Чернігівська політехніка». 2020. № 3(23). С. 26-32.

10. Парубець О. М. Розробка методики оцінки рівня інформатизації транспортного сектору України як запорука його конкурентоспроможності. Технологический аудит и резервы производства. 2016. № 4/5 (30). С. 42-46. DOI: 10.15587/2312-8372.2016.76624.

11. Рекун Г. П., Маліновська Я. С. Особливості використання технологій підбору персоналу на підприємстві. Науковий вісник Міжнародного гуманітарного університету. 2015. № 1. C. $114-118$.

12. Смачило В. В. Архітектоніка трансформацій кадрового потенціалу підприємств транспорту. Економіка та держава. 2019. № 7. С. 39-45.

13. Сурмін Ю. П. Кейс-стаді: архітектура і можливості. Київ : Навч.-метод. центр «Консорціум із удосконалення менеджмент-освіти в Україні», 2012. $336 \mathrm{c.}$

14. Чернова Н. С., Сурмило Д. С. Стратегічне планування потреби в персоналі транспортної галузі. Економічні інновації. 2017. № 65. С. 179-186.

15. Что такое Action Learning («Обучение действием»)? URL: https://www.youtube.com/ watch? $\mathrm{v}=\mathrm{UfVe}-68 \mathrm{YCmc}$.

16. Шеховцова I. А., Годована А. С. Роль коучингу в політиці ефективного управління персоналом. Сучасні проблеми економіки і підприємнищтва. 2016. № 17. С. 159-164.

17. Andrews, Dee; Hull, Donahue Storytelling As an Instructional Method: Descriptions and Research Question. Interdisciplinary Journal of Problem-Based Learning. 2009. Pp. 6-23.

18. HR-тренды 2018: десять инноваций, которые в корне изменят отношения на рынке труда. URL: https://hh.ru/article/505209.

\section{References}

1. State Statistics Service of Ukraine. (n.d.). http://www.ukrstat.gov.ua.

2. Iliash, O. I., Blokhin, P. V. (2018). Maibutnie HR menedzhmentu: tendentsii, ryzyky, motyvatsiia. [The future of HR management: trends, risks, motivation]. Efektyvna ekonomika Efficient economy, 10. http://ojs.dsau.dp.ua/index.php/efektyvna-ekonomika/article/view/1484.

3. Innovatsiina Ukraina 2020: natsionalna dopovid [Innovative Ukraine 2020: national report]. (2015). Kyiv.

4. Kichko, I. I., Gorbacheva, O. Yu. (2017). Innovatsiini metody pidboru ta otsinky personalu [Innovative Methods of Selection and Evaluation of the Personnel]. Problemy i perspektyvy ekonomiky ta upravlinnia - Problems and prospects of economics and management, (2), pp. 7-14.

5. Koba, V. H., Shelest, T. M. (2018). Ekonomichni aspekty pidhotovky moriakiv v Ukraini. [Economic aspects of sailors training in Ukraine]. Vodnyi transport - Water transport, (1), pp. 74-78.

6. Kompaniiets, V. V., Polova, V. V. (2016). Upravlinnia trudovoiu povedinkoiu pratsivnykiv pidpryiemstva zaliznychnoho transportu (sotsiokulturni dominanty) [Management of labor behavior of employees of the railway transport enterprise (sociocultural dominants)]. Lider.

7. Kryvoruchko, O. M., Vodolazhska, T. O. (2013). Pidkhid do formuvannia stratehii upravlinnia personalom ATP. [Approach to the formation of ATP personnel management strategies.]. Ekonomika transportnoho kompleksu - Economics of the transport complex, (22), pp. 97-107.

8. Nazarenko, I. L., Trush, I. M. (2019). Orhanizatsiino-ekonomichnyi mekhanizm upravlinnia kadrovym potentsialom strukturnoho pidrozdilu zaliznychnoho transportu [Organizational and economic mechanism of personnel potential management of the structural subdivision of railway transport]. Visnyk ekonomiky transportu i promyslovosti - Bulletin of Transport Economics and Industry, (66), pp. 94-102.

9. Parubets, O. M. (2020). Doslidzhennia vplyvu koronakryzy na stan transportnoho sektoru Ukrainy.[Study of the Influence of the Corona Crisis on the Condition of the Transport Sector of Ukraine]. Problemy i perspektyvy ekonomiky ta upravlinnia - Problems and prospects of economics and management, (3(23)), pp. 26-32. 
10. Parubets, O. M. (2016). Rozrobka metodyky otsinky rivnia informatyzatsii transportnoho sektoru Ukrainy yak zaporuka yoho konkurentospromozhnosti [Assessment method development of informatization level for transport sector in Ukraine as a guarantee of its competitiveness]. Tekhnologicheskii audit i rezervy proizvodstva - Technology Audit and Production Reserves, 4(5(30)), pp. 42-46. DOI: $10.15587 / 2312-8372.2016 .76624$.

11. Rekun, H. P., Malinovska, Ya. S. (2015). Osoblyvosti vykorystannia tekhnolohii pidboru personalu na pidpryiemstvi [Features of use of technologies of selection of the personnel at the enterprise]. Naukovyi visnyk Mizhnarodnoho humanitarnoho universytetu - Scientific Bulletin of the International Humanities University, (1), pp. 114-118.

12. Smachylo, V. V. (2019). Arkhitektonika transformatsii kadrovoho potentsialu pidpryiemstv transportu. [Architectonics of transformations of personnel potential of transport enterprises]. Ekonomika ta derzhava - Economy and state, (7), pp. 39-45.

13. Surmin, Ju. P. (2012). Keis-stadi: arkhitektura i mozhlyvosti [Case studies: architecture and possibilities]. Navchalno-metodychny tsentr Konsortsium is udoskonalennja menedzhment-osvity v Ukraini.

14. Chernova, N. S., Surmylo, D. S. (2017). Stratehichne planuvannia potreby v personali transportnoi haluzi [Strategic Personnel Requirements Planning in the Transport Industry]. Ekonomichni innovatsii - Economic innovations, (65), pp. 179-186.

15. Chto takoe Action Learning («Obuchenye deistvyem»)? [What is it Action Learning]. $\mathrm{https}: / /$ www.youtube.com/watch?v=UfVe-68YCmc.

16. Shekhovtsova, I. A., Hodovana, A. S. (2016). Rol kouchynhu v politytsi efektyvnoho upravlinnia personalom [The role of coaching in the policy of effective personnel management]. Suchasni problemy ekonomiky i pidpryiemnytstva - Modern problems of economy and entrepreneurship, (17), pp. 159-164.

17. Andrews, Dee; Hull, Donahue (2009). Storytelling as an Instructional Method: Descriptions and Research Question. Interdisciplinary Journal of Problem-Based Learning, pp. 6-23.

18. HR-trendy 2018: desiat ynnovatsyi, kotorye v korne yzmeniat otnoshenyia na rynke truda. [HR trends 2018: ten innovations that will radically change attitudes in the labor market]. https://hh.ru/article/505209.

Парубець Олена Миколаївна - доктор економічних наук, професор, професор кафедри фінансів, банків-

ської справи та страхування, Національний університет «Чернігівська політехніка» (вул. Шевченка, 95, м. Чернігів, 14035, Україна).

Парубец Елена Николаевна - доктор экономических наук, профессор, профессор кафедры финансов, бан-

ковского дела и страхования, Национальный университет «Черниговская политехника» (ул. Шевченко, 95,

г. Чернигов, 14035, Украина).

Parubets Olena - Doctor of Economic Sciences, Professor, Professor of Department of Finance, Banking and Insurance, Chernihiv Polytechnic National University (95 Shevchenka Str., 14035 Chernihiv, Ukraine).

E-mail: olena.parubets@gmail.com

Orcid: orcid.org/0000-0001-5357-7581

Researcher ID: H-5503-2015

Кичко Ірина Іванівна - доктор економічних наук, професор, професор кафедри управління персоналом та економіки праці, Національний університет «Чернігівська політехніка» (вул. Шевченка, 95, м. Чернігів, 14035, Україна).

Кичко Ирина Ивановна - доктор экономических наук, профессор, профессор кафедры управления персоналом и экономики труда, Национальный университет «Черниговская политехника» (ул. Шевченко, 95, г. Чернигов, 14035, Украина)

Kychko Iryna -Doctor of Economic Sciences, Professor, Professor of Department of Personnel Management and

Labour Economy, Chernihiv Polytechnic National University (95 Shevchenka Str., 14035 Chernihiv, Ukraine).

E-mail: ira41215@ukr.net 